\title{
HUBUNGAN ANTARA EXPERIENTIAL MARKETING, LAYANAN RESTORAN PRASMANAN, CUSTOMER SATISFACTION DAN CUSTOMER LOYALTY
}

\author{
Grace Chintia Sutanto \\ Universitas Negeri Surabaya \\ gracesutanto16080574062@mhs.unesa.ac.id \\ Tias Andarini Indarwati \\ Universitas Negeri Surabaya \\ tiasindarwati@unesa.ac.id
}

\begin{abstract}
Every company wants its brand to be a major concern for consumers. Experiential marketing is a way of marketing that not only sells products but also creates them accompanied by emotional experiences that touch consumers' hearts. One of the businesses that are using experiential marketing is Hanamasa Restaurant which is a Japanese restaurant with buffet service type. The purpose of this research is to investigate the effect of experiential marketing and service attributes on buffet restaurants on customer loyalty with customer satisfaction as a mediating variable, a case study of Hanamasa consumers in Surabaya. Path analysis using AMOS 24 and IBM SPSS was performed for statistical analysis. Research with 110 respondents was taken with nonprobability sampling techniques. Criteria for respondents in this study are at least 19 years old and have visited Hanamasa at least twice in the past one to six months. The results of this study are experiential marketing a positive effect on customer satisfaction both through customer loyalty and directly. Likewise, the effect of service attributes on buffet restaurants has a positive impact on customer satisfaction but not on customer loyalty.
\end{abstract}

Keywords: customer loyalty; customer satisfaction; experiential marketing; service attributes on buffet restaurant.

\section{PENDAHULUAN}

Perubahan sudut pandang terhadap restoran saat ini membuat industri kuliner menjadi sangatlah penting. Badan Ekonomi Kreatif (Bekraf) menyatakan bahwa bisnis kuliner tidaklah sekedar kebutuhan hidup namun telah menjadi gaya hidup. Pertumbuhan bisnis restoran di Surabaya menunjukkan peningkatan yang signifikan. Data Badan Pusat Statistik mencatat terjadinya pertumbuhan secara terus menerus pada restoran di Kota Surabaya pada tahun 2015 hingga tahun 2019. Mulai tahun 2015 ke tahun berikutnya terdapat pertumbuhan jumlah restoran sebesar 11\%,37\%, dan $23 \%$ hingga tahun 2018 . Pada pertengahan Februari tahun 2019 pertumbuhan bisnis kuliner di Surabaya adalah 20\% (Wijayanto, 2019).

Melihat semakin ketatnya persaingan di industri kuliner saat ini, pemilik bisnis membutuhkan kemampuan bertahan agar terus bertumbuh. Kemampuan pertahanan di tengah persaingan kompetitif menuntut pemenuhan kebutuhan layanan berkualitas dan berkelanjutan pada bisnis restoran (Stamenkovic \& Milanovic, 2010; Diab et al., 2015). Kemampuan ini berimplikasi pada kelayakan finansial jangka panjang serta kesuksesan bisnis berkelanjutan (Suzana et al., 2010). Dasar inilah yang menjadikan pentingnya bisnis restoran untuk menyediakan layanan berkualitas yang lebih tangguh di pasar yang dinamis saat ini.

Restoran Hanamasa ialah salah satu restoran Jepang dengan tipe pelayanan buffet yang mampu bertahan sejak tahun 1987 di Indonesia. Hingga saat ini, restoran bertaraf internasional ini memiliki memiliki dua cabang di Surabaya yaitu daerah Gubeng Pojok dan Tunjungan Plaza (hanamasaresto.com, 2020). Restoran ini dikenal dengan konsep all you can eat atau konsep restoran yang memanjakan konsumen dengan makan sepuasnya namun hanya dengan sekali bayar (restofocus.com, 2019). Harga yang berlaku dalam konsep all you can eat relatif lebih mahal dari restoran pada umumnya, hal ini dinamakan dengan sistem flat rate, konsumen membayar harga yang terbilang mahal, serta dapat menyantap 
hidangan apapun yang tersaji di meja buffet sepuasnya atau semampu mereka mengonsumsi (Warisan dan Harianto, 2018).

Tabel 1.

PERINGKAT RESTORAN ALL YOU CAN EAT 2019

\begin{tabular}{lcccc}
\hline \multicolumn{1}{c}{ Nama Restoran } & Jenis Makanan & Rating & Jumlah Cabang & Tahun Berdiri \\
\hline Gyu - Kaku & Jepang & $4,6 / 5$ & 26 & 1996 \\
Shaburi Shabu-Shabu & Jepang & $4,4 / 5$ & 31 & 2013 \\
Hanamasa & Jepang & $4,3 / 5$ & 28 & 1987 \\
Cocari & Jepang & $4,3 / 5$ & 2 & 2018 \\
BBQ Frenzy & Korea & $3,8 / 5$ & 2 & 2016 \\
\hline
\end{tabular}

Sumber: Tripadvisor (2019); Traveloka (2019); Pergikuliner (2019), data diolah

Data peringkat restoran dari tiga sumber data yang telah diolah berdasarkan jumlah rating sesuai dengan tabel 1 menunjukkan terdapat lima restoran all you can eat teratas dengan sistem buffet di Surabaya. Hanamasa sebagai restoran paling lama berdiri menduduki peringkat ketiga jika dibandingkan dengan nilai rata-rata rating. Meskipun sudah lama berdiri di Indonesia, Hanamasa mampu bertahan dalam persaingan di industri kuliner dan juga dapat bertumbuh dengan bany aknya jumlah cabang di Indonesia. Hal ini mengindikasikan bahwa Restoran Hanamasa merupakan restoran prasmanan yang menguntungkan dan bertolak belakang dengan penelitian Raab dan Mayer (2007) yang meneliti restoran prasmanan di Hongkong, menyatakan bahwa hanya ada tiga menu yang menghasilkan keuntungan dari dua puluh menu prasmanan yang disajikan. Berarti tujuh belas menu sisanya tidak menghasilkan keuntungan atau merugikan pihak restoran.

Untuk menjadi restoran all you can eat andalan konsumen, tidaklah cukup hanya menyajikan hidangan restoran yang tersedia di atas meja. Dibutuhkan keunikan atau ciri khas yang menjadi pembeda dari restoran all you can eat lainnya. Restoran perlu mendapatkan informasi terkait kebutuhan dan keinginan konsumen agar dapat memberikan produk dan layanan yang berkualitas (Ivkov et al., 2014). Experiential marketing adalah cara yang ideal bagaimana memperlakukan pelanggan untuk meningkatkan loyalitas dan keterlibatan pelanggan saat makan di restoran (Patel, 2019). Menurut Schmitt (1999), tujuan pemasaran tidak semata-mata untuk mendapatkan kepuasan pelanggan saja, ataupun pemecahan masalah atas kebutuhan akan utilitas produk. Lebih dari itu semua, tujuan utamanya ialah untuk memberikan momen yang berkesan terhadap pelanggan. Experiential marketing meyodorkan sistem kerja dengan kombinasi kesenangan dan rekreasi yang identik dengan peristiwa tak terlupakan pada produk yang disediakan.

Penelitian yang dilakukan oleh Zena dan Hadisumarto (2012) dengan subjek konsumen kafe serta Liu et al., (2016) dengan subjek konsumen restoran fast food yang menggunakan experiential marketing sebagai variabel independen, menyatakan hubungan positif pada customer loyalty. Perolehan berbeda ditunjukkan dari penelitian Fang dan Chao (2015) dengan subjek anggota fitness club yang menyatakan bahwa experiential marketing tidak berpengaruh signifikan terhadap customer loyalty.

Perusahaan harus menyadari dan memperhatikan cara membuat dan meningkatkan kualitas layanan atau layanan yang ditawarkan. Kualitas layanan yang telah dibuat dan yang akan ditingkatkan tidak dapat diukur dari sudut pandang perusahaan, tetapi dari sudut pandang pelanggan atau persepsi kualitas (Kotler, 2007: 9). Kim dan Choi (2019) telah merangkum sedikitnya dua puluh empat penelitian terkait kualitas layanan pada berbagai jenis restoran. Kualitas layanan restoran memiliki fitur khas yang menjadi pembeda dengan bidang layanan lainnya. Kim dan Choi menyadari adanya ketidaksamaan dan persamaan antara atribut layanan restoran yang diprioritaskan oleh pelayanan restoran dan atribut layanan restoran yang penting bagi pelanggan. Sehingga ditemukan beberapa atribut layanan khusus pada restoran prasmanan yang disebut layanan restoran prasmanan atau dengan kata lain service attributes on buffet restaurants. 
Menurut Tjiptono (2001, p.146) customer satisfaction adalah evaluasi setelah pembelian dimana alternatif yang dipilih sesuai atau melampaui harapan pelanggan, sedangkan ketidakpuasan timbul apabila hasil tidak memenuhi harapan. Customer satisfaction merupakan reaksi emosional jangka pendek pelanggan terhadap kinerja jasa tertentu (Lovelock, 2005, p.102). Pelanggan yang puas cenderung akan melakukan pembelian ulang dan menjadi loyal terhadap layanan atau produk yang ditawarkan oleh perusahaan. Terciptanya kepuasan pelanggan dapat memberikan manfaat, di antaranya hubungan antara perusahaan dan pelanggan menjadi harmonis, memberikan dasar yang baik bagi pembelian ulang dan terciptanya loyalitas pelanggan, dan membentuk suatu rekomendasi dari mulut ke mulut (word of mouth) yang menguntungkan bagi perusahaan (Tjiptono, 2008, p.24). Oleh karena itu, loyalitas pelanggan harus berdasarkan kepuasan dan pembelian secara berkelanjutan. Selain itu, kualitas layanan, kepuasan pelanggan dan loyalitas telah menjadi konstruksi sejak studi awal industri restoran. Menurut Kotler (2009) hubungan antara kepuasan dan loyalitas adalah saat dimana konsumen mencapai tingkat kepuasan tertinggi yang menimbulkan ikatan emosi kuat serta komitmen jangka panjang dengan merek perusahaan. Beberapa penelitian melaporkan hubungan positif antara kualitas layanan, kepuasan pelanggan dan loyalitas dalam industri restoran (Kuo, et al, 2011). Diab, et al (2015) yang meneliti hubungan kepuasan dengan loyalitas pada pengunjung restoran di Sudan menyatakan adanya hubungan positif antara kepuasan dan loyalitas pelanggan. Sebab kepuasan pelanggan berakibat pada loyalitas pelanggan sehingga pelanggan tersebut dengan senang memberikan rekomendasi pada orang lain (Rahmani, 2018). Penelitian ini bertujuan untuk mengetahui bagaimana experiential marketing dan layanan restoran prasmanan mempengaruhi loyalitas baik secara langsung maupun menggunakan kepuasan pelanggan sebagai variabel mediasi dengan studi yang dilakukan pada Restoran Hanamasa di Surabaya.

\section{KAJIAN PUSTAKA DAN PENGEMBANGAN HIPOTESIS}

\section{Experiential Marketing}

Titik fokus sistem pemasaran tradisional terdapat pada rasionalitas konsumen, dimana konsumen membeli produk yang memiliki fitur dan keuntungan atau manfaat. Seiring berjalannya waktu dan pertumbuhan bisnis sehingga persaingan semakin sengit, terdapat perubahan pada sistem pemasaran yang dikenal sebagai experiential marketing. Experiential marketing merupakan pendekatan pemasaran dengan menciptakan emosi dan perasaan yang terlibat pada konsumen sehingga memberikan pengalaman-pengalaman positif yang tidak terlupakan. Akibatnya konsumen menjadi sangat tertarik terhadap produk tertentu (Schmitt, 1999). Tujuan pemasaran tidak semata-mata untuk mendapatkan kepuasan pelanggan saja, bukan hanya untuk memberikan solusi untuk masalah pelanggan atau untuk memberikan manfaat yang dibutuhkan. Lebih dari itu semua, tujuan utamanya ialah untuk memberikan pengalaman holistik (pengalaman berharga) kepada pelanggan. Experiential marketing memberikan kerangka kerja mengintegrasikan elemen pengalaman dan hiburan ke dalam produk / layanan. Jika diperhatikan saat ini, konsumen tidak hanya menilai suatu produk / layanan berdasarkan kualitas, fungsionalitas, dan manfaat.. Konsumen menginginkan produk, komunikasi, dan kegiatan pemasaran yang memberikan sensasi, menyentuh hati mereka, merangsang kecerdasan mereka, dan menyesuaikan gaya hidup mereka. Dengan kata lain, yang diinginkan konsumen ialah produk yang kehadirannya dapat memberikan pengalaman. Telah ditemukan 5 jenis pengalaman yang dinamakan strategic experience modules (SEMs), yaitu: pengalaman indera (sense), pengalaman perasaan / afektif (feel), pengalaman pemikiran kognitif kreatif (think), pengalaman tindakan fisik (act), identitas sosial / pengalaman berhubungan (relate) (Schmitt, 1999).

\section{Layanan Restoran Prasmanan}

Restoran prasmanan atau buffet restaurants merupakan salah satu tipe pelayanan restoran self service dimana hidangan diletakkan di atas meja dan tamu mengambil hidangannya sendiri sesuai selera (Arief, 2005, p. 37). all you can eat buffet restaurant, (Oyewole, 2013) mendefinisikan sebagai konsep restoran yang memberikan hak kepada pengunjung untuk makan sepuasnya dengan satu harga. Temuan terbaru, Kim dan Choi (2019) telah merangkum dua puluh empat penelitian terkait kualitas layanan pada berbagai jenis restoran. Kualitas layanan restoran memiliki fitur khas yang menjadi pembeda dengan bidang layanan lainnya. Telah disadari adanya ketidaksamaan dan persamaan antara atribut layanan restoran yang diprioritaskan oleh pelayanan restoran dan atribut layanan restoran yang penting bagi 
pelanggan. Sehingga ditemukan beberapa atribut layanan di restoran prasmanan yang disebut layanan restoran prasmanan atau dengan kata lain service attributes on buffet restaurants. Telah ditemukan empat atribut layanan pada restoran prasmanan all you can eat, yaitu sebagai berikut: food quality atau kualitas makanan dapat diukur dari rasa makanan, kesegaran makanan seperti daging dan sayuran mentah yang tersedia dan variasi menu yang disajikan; interior atau bagian dalam ruangan restoran prasmanan yang diukur dari dekorasi dan desain interior, pengaturan meja, dan kebersihan lingkungan; service quality atau kualitas layanan yang dimaksud pada restoran prasmanan ialah diukur dari respon layanan yang cepat, perilaku bijak dan ramah karyawan, dan pemulihan kegagalan layanan yang efisien; price and value atau harga dan nilai ialah salah satu faktor penting bagi konsumen dalam memilih restoran. Kedua hal ini dapat diukur dari nilai mutlak dan harga yang diminta, nilai untuk harga komparatif dan masuk akal dan nilai keseluruhan dari pengalaman bersantap. Layanan restoran prasmanan merupakan kualitas layanan pada restoran prasmanan yang memainkan peran penting dalam menciptakan kepuasan pelanggan (Diab et al., 2015).

\section{Customer Satisfaction}

Temuan terdahulu (Engel, Blackwell, dan Miniard, 2012) menyatakan bahwa kepuasan pelanggan merupakan evaluasi purna beli dimana alternatif yang dipilih sekurang-kurangnya sama atau melampaui harapan pelanggan. Pada penelitian ini digunakan customer satisfaction sebagai variabel mediasi karena kepuasan konsumen adalah salah satu faktor pendorong loyalitas Vanessa (2007, p.72). Penelitian ini menggunakan indikator dari Diaz dan Consuegra (2018) untuk mengukur kepuasan dengan pertimbangan penyesuaian dari objek yang diteliti dan mengurangi pernyataan yang ambigu, di antaranya: restoran ini memenuhi harapan saya; secara keseluruhan saya puas dengan layanan yang ditawarkan; layanan yang ditawarkan melebihi harapan saya.

\section{Customer Loyalty}

Menurut Liu dan Jang (2009), untuk mempertahankan pelanggan, pemicu utamanya adalah intensitas kepuasan pelanggan. Loyalitas menurut Noegroho et al., (2013) adalah wujud perilaku dari keputusan yang diambil untuk melakukan pembelian secara berulang terhadap barang atau jasa suatu perusahaan. Ketika hubungan ini bergabung dalam satu model, anteseden, mediasi, dan konsekuensi dapat ditunjukkan dengan jelas, maka dapat diterima secara logika untuk memperkirakan bahwa kepuasan pelanggan berfungsi sebagai mediasi yang diperlukan antara kualitas layanan dan loyalitas pelanggan (Kuo, 2011). Menurut Griffin (2005, p.31), indikator loyalitas pelanggan adalah sebagai berikut: repeat purchase atau melakukan pembelian ulang; retention atau menunjukkan kekebalan terhadap tawaran pesaing; referalls atau memberitahukan kepada orang lain mengenai kepuasan yang didapat.

\section{Hubungan antar Variabel}

Menurut teori yang dijelaskan oleh Kotler dan Keller (2007, p.177), ketika konsumen merasa gembira maupun kecewa pasca mengevaluasi produk, antara harapan konsumen dengan kenyataan inilah yang dinamakan kepuasan konsumen. Wu dan Tseng (2015) menyebutkan karena adanya pengalamanpengalaman yang menyenangkan hati pelanggan, menyebabkan peningkatan kepuasan pelanggan. Schmitt (1999) menunjukkan bahwa tujuan experiential marketing adalah guna meningkatkan kepuasan pelanggan. Hasil penelitian oleh Zena dan Hadisumarto (2012) menyimpulkan bahwa experiential marketing menunjukkan hasil signifikan positif terhadap customer satisfaction. Penelitian Indarwati dan Tiarawati (2015) juga memberikan hasil yang signifikan positif antara experiential marketing terhadap customer satisfaction.

H1: Experiential marketing berpengaruh positif terhadap customer satisfaction Restoran Hanamasa di Surabaya.

Teori yang dijelaskan oleh (Ayse, 2007, p.53) menyatakan bahwa ekspektasi dari konsumen adalah pemicu utama, kuatnya relasi antara kualitas layanan dengan kepuasan konsumen melahirkan ekspektasi lebih tinggi serta berlaku sebaliknya. Wei dan Hung (2010) menunjukkan bahwa pemasaran pengalaman berhubungan positif dengan kepuasan pelanggan dalam temuan empirisnya. Penelitian yang dilakukan oleh Kim dan Choi (2019) pada objek the korean all you can eat buffet menyatakan 
Grace Chintia Sutanto dan Tias Andarini Indarwati. Hubungan antara Experiential Marketing, Layanan Restoran Prasmanan, Customer Satisfaction, dan Customer Loyalty

bahwa ada beberapa studi yang menyinergikan perspektif atau harapan pelanggan dan operator layanan untuk meningkatkan kepuasan pelanggan sehingga efisiensi layanan dapat dimaksimalkan. Hasil penelitian dari Ramanathan (2016) dengan variabel penelitian layanan restoran prasmanan (buffet), menyatakan layanan restoran prasmanan berpengaruh signifikan terhadap customer satisfaction.

H2: Layanan Restoran Prasmanan berpengaruh positif terhadap customer satisfaction Restoran Hanamasa di Surabaya.

Vanessa (2007) menjelaskan bahwa loyalitas dipengaruhi oleh lima faktor, dan salah satunya adalah kepuasan. Menurut Wu dan Tseng (2015) kepuasan pelanggan dapat diarahkan kepada loyalitas pelanggan. Sikap konsumen akan dikembangkan setelah menggunakan produk atau layanan. Jika mereka merasa puas dengan produk atau layanan, probabilitas mereka untuk membelinya kembali menjadi lebih tinggi. Dalam jangka panjang, mereka segera mengembangkan sikap untuk loyal terhadap produk atau layanan. Penelitian yang dilakukan oleh El Adly (2018) dengan subjek pengunjung hotel dan Carranza dan Consuegra (2018) dengan subjek restoran fast food menyatakan bahwa customer satisfaction berpengaruh signifikan terhadap customer loyalty.

H3: Customer satisfaction berpengaruh positif terhadap customer loyalty Restoran Hanamasa di Surabaya.

Kertajaya (2010, p.23) menjelaskan jika experiential marketing sama dengan rancangan pemasaran bertujuan untuk terbentuknya kesetiaan konsumen dari sentuhan emosi tertentu sehingga terciptanya momen berharga yang menyenangkan bagi konsumen terhadap suatu produk. Araci (2017) menyebutkan salah satu keunggulan menerapkan experiential marketing ialah menciptakan loyalitas merek sehingga didapatkan pelanggan yang loyal. Schmitt (1999) menyebutkan bahwa menciptakan pengalaman yang menyenangkan bagi pelanggan adalah kunci untuk loyalitas pelanggan, dan pelanggan yang setuju dengan experiential marketing yang mereka alami cenderung menunjukkan loyalitas yang lebih tinggi. Chen dan Lee (2009) menunjukkan adanya usaha yang dapat meningkatkan arti, perasaan, dan cara berpikir dapat menyebabkan loyalitas yang lebih tinggi. Penelitian terdahulu oleh Zena \& Hadisumarto (2012) dengan subjek konsumen pada kafe dan (Liu et al., 2016) dengan subjek konsumen restoran fast food yang menggunakan experiential marketing sebagai variabel independen dan menyatakan hubungan positif pada customer loyalty.

H4: Experiential marketing berpegaruh positif terhadap customer loyalty Restoran Hanamasa di Surabaya.

Oyewole (2013) menyatakan bahwa menyediakan layanan berkualitas yang mampu memenuhi kebutuhan serta keinginan pelanggan adalah strategi yang diperlukan untuk kelangsungan hidup dan keberhasilan perusahaan jasa, karena ada pengaruh positif yang signifikan dari kualitas pada kepuasan pelanggan, niat pembelian kembali, dan loyalitas. Kim dan Choi (2019) telah menelaah beberapa penelitian terdahulu mengenai atribut layanan restoran Korea dengan konsep all you can eat dari perpektif pelanggan dan dan telah melakukan analisis efek kualitas layanan pada loyalitas pelanggan yang dapat memengaruhi secara signifikan. Loyalitas menurut Griffin (2005, p.5) adalah konsumen yang sangat puas dengan produk atau jasa tertentu sehingga mempunyai antusiasme untuk memperkenalkan kepada siapapun yang mereka kenal. Penelitian (Kuo et al., 2011) dengan variabel service quality pada industri restoran menyatakan adanya hubungan positif dan signifikan pada customer loyalty. Hubungan antar variabel juga digambarkan di Gambar 1.

H5: Layanan Restoran Prasmanan berpengaruh positif terhadap customer loyalty Restoran Hanamasa di Surabaya. 


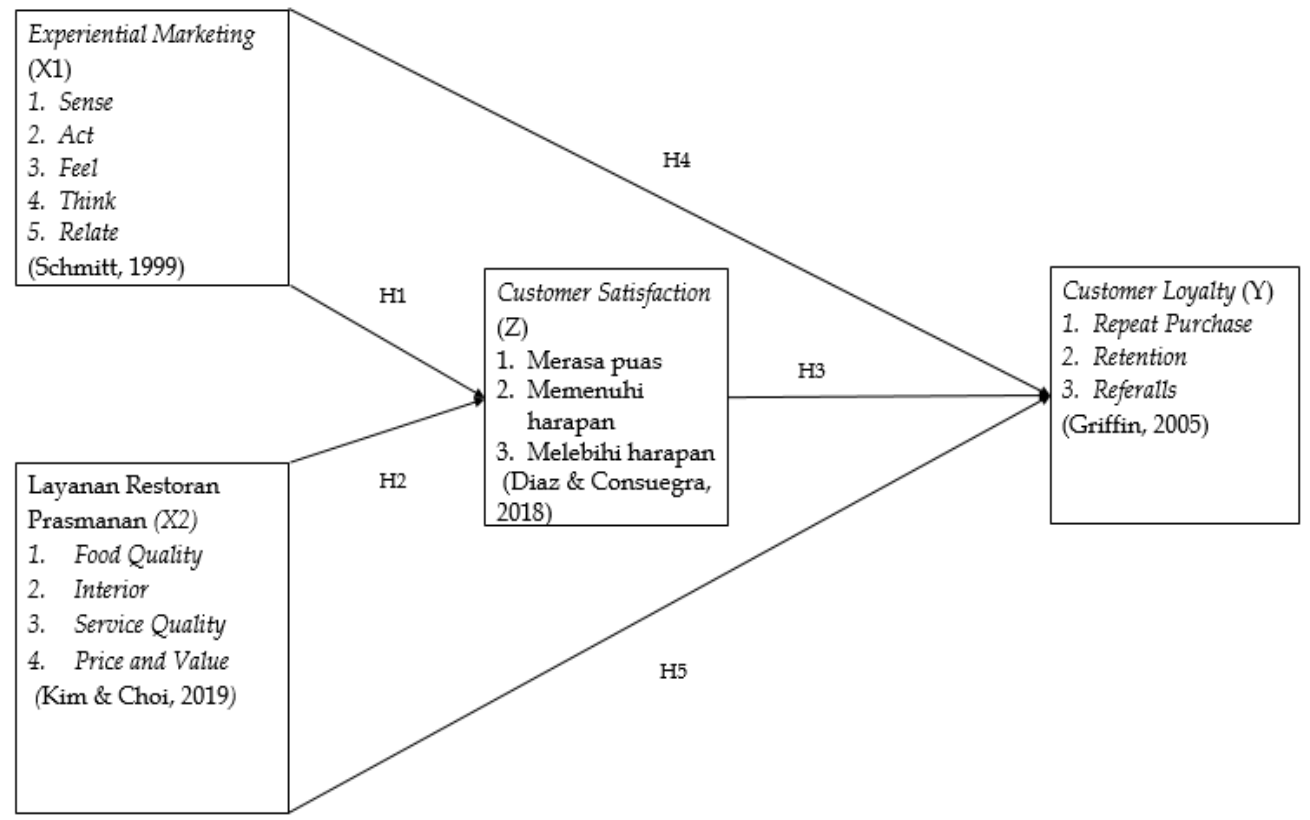

Gambar 1. KERANGKA KONSEPTUAL PENELITIAN

\section{METODE PENELITIAN}

Penelitian ini merupakan penelitian kausalitas atau penelitian sebab akibat dengan pendekatan kuantitatif. Konsumen Restoran Hanamasa Surabaya adalah populasi dalam penelitian ini. Sampel sebanyak 110 respoden dengan menggunakan teknik nonprobability sampling dengan metode judgemental sampling. Sumber data yang digunakan dalam penelitian ini adalah data sekunder. Data sekunder diperoleh secara tidak langsung seperti dari artikel, jurnal, dan buku-buku yang mendukung penelitian ini, termasuk cara menyebarkan angket kepada responden (secara online). Instrumen pernyataan menggunakan pilihan jawaban dengan skala likert. Skala likert adalah skala pengukuran yang menggunakan lima kategori respon yang berkisar antara sangat tidak setuju, tidak setuju, cukup setuju, setuju dan sangat setuju, yang mengharuskan responden menentukan derajat persetujuan atau ketidaksetujuan mereka terhadap masing-masing pernyataan mengenai objek stimulus. Kriteria responden penelitian ini ialah minimal berusia 19 tahun serta pernah mengunjungi Hanamasa minimal dua kali dalam kurun waktu satu hingga enam bulan lalu (September 2019 hingga Februari 2020). Terdapat dua jenis variabel yang digunakan dalam penelitian ini yakni experiential marketing dan layanan restoran prasmanan variabel eksogen, customer satisfaction sebagai variabel mediasi dan customer loyalty sebagai variabel endogen. Path analysis menggunakan software AMOS versi 24.0 dan IBM SPSS 23 dilakukan pada penelitian ini untuk analisis statistik dan analisis statistik inferensial.

\section{HASIL DAN PEMBAHASAN}

Hasil dari uji validitas pada semua variabel dalam penelitian ini menunjukkan bahwa $r$ hitung $>r$ tabel $(0,361)$, sehingga semua item pernyataan kuesioner dinyatakan valid. Pada uji reliabilitas semua variabel, dinyatakan bahwa nilai cronbach's alpha based on standardized items $>0,60$. Sehingga variabel yang diukur sudah reliable.

Tabel 2 menunjukkan dominasi karakteristik responden pada penelitian ini. Bagian persyaratan uji analisis jalur yang dilakukan pada penelitian ini antara lain uji normalitas, uji linearitas, uji outlier, uji multikolinearitas dan juga uji kelayakan model. Pada uji normalitas, model memenuhi asumsi normalitas karena nilai CR (critical ratio) berada di antara $\pm 2,58$. Pada uji linieritas, model memenuhi asumsi karena nilai sig. sebesar 0.000 atau $<0,05$. Pada uji outlier model juga memenuhi asumsi outlier karena nilai dari p2 semuanya $>0,05$. Uji multikolinearitas menyatakan bahwa determinant of sample covariance matrix sebesar 5553,726 > 0 dengan condition number 36,159. Untuk uji kelayakan model, hasil dari koefisien determinasi didapatkan sebesar $91,5 \%$ yang mana hal tersebut menjelaskan bahwa 
Grace Chintia Sutanto dan Tias Andarini Indarwati. Hubungan antara Experiential Marketing, Layanan Restoran Prasmanan, Customer Satisfaction, dan Customer Loyalty

model dapat mempengaruhi variabel endogen sebesar 91,5\% dan sisanya sebesar 8,5\% dijelaskan oleh variabel lainnya yang tidak terlibat dalam model.

Tabel 2.

\section{KARAKTERISTIK RESPONDEN}

\begin{tabular}{|c|c|c|c|}
\hline \multicolumn{2}{|c|}{ Keterangan } & \multirow{2}{*}{$\begin{array}{c}\text { Frekuensi } \\
102\end{array}$} & \multirow{2}{*}{$\begin{array}{c}\% \\
92,7\end{array}$} \\
\hline Usia & 19-29 tahun & & \\
\hline & 30-40 tahun & 5 & 4,5 \\
\hline & 41-51 tahun & 2 & 1,8 \\
\hline & $>51$ tahun & 1 & 1 \\
\hline \multirow[t]{2}{*}{ Jenis Kelamin } & Laki-laki & 32 & 29,1 \\
\hline & Perempuan & 78 & 70,9 \\
\hline \multirow{4}{*}{ Pendidikan Terakhir } & SMA & 63 & 57,3 \\
\hline & Diploma & 12 & 10,9 \\
\hline & Sarjana & 32 & 29,1 \\
\hline & Lainnya & 3 & 2,7 \\
\hline \multirow[t]{6}{*}{ Pekerjaan } & Mahasiswa/Pelajar & 61 & 55,4 \\
\hline & PNS & 2 & 1,8 \\
\hline & Pegawai Swasta & 27 & 24,5 \\
\hline & Wiraswasta & 8 & 7,3 \\
\hline & Ibu Rumah Tangga & 6 & 5,5 \\
\hline & Lainnya & 6 & 5,5 \\
\hline \multirow[t]{7}{*}{ Pengeluaran per bulan } & $<\operatorname{Rp} 1.000 .000$ & 27 & 24,5 \\
\hline & $\operatorname{Rp} 1.000 .001-\operatorname{Rp} 1.500 .000$ & 24 & 21,9 \\
\hline & $\operatorname{Rp} 1.500 .001-\operatorname{Rp} 2.000 .000$ & 14 & 12,7 \\
\hline & $\mathrm{Rp} 2.000 .001-\mathrm{Rp} 3.000 .000$ & 15 & 13,6 \\
\hline & Rp $3.000 .001-\operatorname{Rp} 5.000 .000$ & 20 & 18,2 \\
\hline & $\operatorname{Rp} 5.000 .001-\operatorname{Rp} 7.000 .000$ & 6 & 5,5 \\
\hline & $>\operatorname{Rp} 7.000 .000$ & 4 & 3,6 \\
\hline Terakhir berkunjung ke & $1-3$ bulan yang lalu & 41 & 37,3 \\
\hline Hanamasa & $4-6$ bulan yang lalu & 69 & 62,7 \\
\hline \multirow{2}{*}{ Frekuensi kunjungan } & 2 kali & 68 & 61,8 \\
\hline & $>2$ kali & 42 & 38,2 \\
\hline Sumber informasi tentang & Teman & 54 & 49,2 \\
\hline \multirow[t]{3}{*}{ Hanamasa } & Keluarga & 27 & 24,5 \\
\hline & Media Sosial & 24 & 21,8 \\
\hline & Lainnya & 5 & 4,5 \\
\hline Total & & 110 & 100 \\
\hline
\end{tabular}

Sumber: Output SPSS, data diolah

\section{Hasil Analisis Path}

Gambar 2 menunjukkan hasil analisis path yang juga dapat dituliskan dalam persamaan model struktural (1) dan (2).

$\mathrm{Z}=0,20 \mathrm{X} 1+0,32 \mathrm{X} 2+0,254$

$\mathrm{Y}=0,17 \mathrm{X} 1+0,09 \mathrm{X} 2+0,49 \mathrm{Z}+0,336$

\section{Uji Hipotesis}

Berdasarkan tabel 3 dapat dilihat hubungan experiential marketing terhadap customer satisfaction mendapatkan nilai CR hitung sebesar 3,748 > 2,00 dan nilai signifikansi 0,00 <0,05. Berdasarkan hasil tersebut maka H1 diterima. Hubungan layanan restoran prasmanan terhadap customer satisfaction mendapatkan nilai CR hitung sebesar 8,370 > 2,00 dan nilai signifikansi 0,00<0,05. Berdasarkan hasil tersebut maka $\mathrm{H} 2$ diterima. Hubungan customer satisfaction terhadap customer loyalty mendapatkan nilai CR hitung sebesar 4,239 > 2,00 dan nilai signifikansi 0,00<0,05. Berdasarkan hasil tersebut maka $\mathrm{H} 3$ diterima. Pengaruh experiential marketing ke customer loyalty mendapatkan nilai CR hitung sebesar 2,492 > 2,00 dan nilai signifikansi $0,013<0,05$. Berdasarkan hasil tersebut maka H4 diterima. 
Hubungan layanan restoran prasmanan terhadap customer loyalty mendapatkan nilai CR hitung sebesar $1,557<2,00$ dan nilai signifikansi 0,119>0,05. Berdasarkan hasil tersebut maka H5 ditolak.

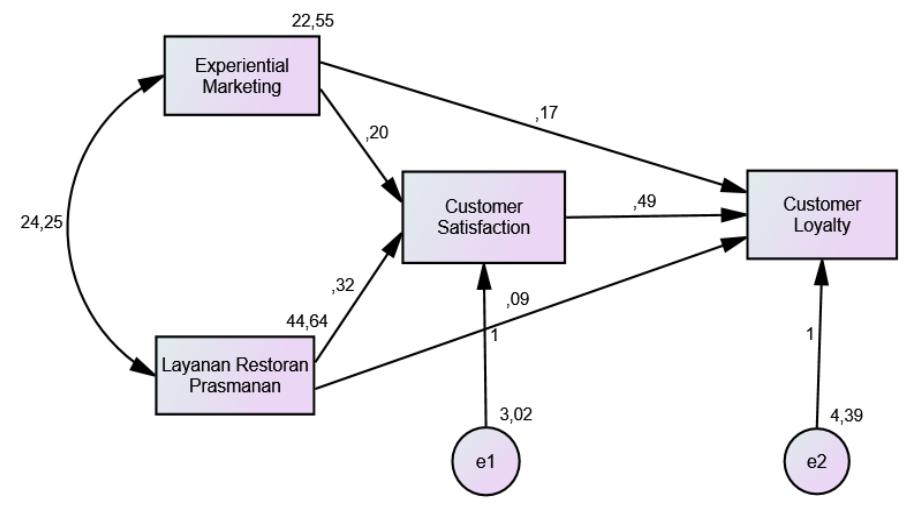

Sumber: Output AMOS, data diolah

Gambar 2. HASIL ANALISIS JALUR

Tabel 3.

HASIL UJI HIPOTESIS

\begin{tabular}{lllcccc}
\hline Hipotesis & \multicolumn{1}{c}{ Variabel } & Estimate & S.E. & C.R. & P \\
\hline H1 & $\begin{array}{l}\text { Korelasi experiential marketing pada customer } \\
\text { satisfaction }\end{array}$ & 0,205 & 0,055 & 3,748 & 000 \\
H2 & $\begin{array}{l}\text { Korelasi layanan restoran prasmanan pada } \\
\text { customer satisfaction }\end{array}$ & 0,325 & 0,039 & 8,370 & 000 \\
H3 & $\begin{array}{l}\text { Korelasi customer satisfaction pada customer } \\
\text { loyalty }\end{array}$ & 0,492 & 0,116 & 4,239 & 000 \\
H4 & $\begin{array}{l}\text { Korelasi experiential marketing pada customer } \\
\text { loyalty }\end{array}$ & 0,174 & 0,070 & 2,492 & 0,013 \\
H5 & $\begin{array}{l}\text { Korelasi layanan restoran prasmanan pada } \\
\text { customer loyalty }\end{array}$ & 0,094 & 0,060 & 1,557 & 0,119 \\
\hline
\end{tabular}

Sumber: Output AMOS, data diolah

\section{Uji Sobel Test}

Hasil dari uji sobel tes nilai probabilitas experiential marketing signifikansinya sebesar $0,0054557(\mathrm{p} \leq$ $0,05)$. Hal ini menunjukkan bahwa variabel experiential marketing memiliki pengaruh signifikan terhadap customer loyalty dengan customer satisfaction sebagai variabel mediasi. Artinya uji mediasi melalui sobel test diterima. Sedangkan nilai probabilitas layanan restoran prasmanan signifikansinya sebesar 0,00019239 ( $\mathrm{p} \leq 0,05)$. Hal ini menunjukkan bahwa variabel layanan restoran prasmanan memiliki pengaruh signifikan terhadap customer loyalty dengan customer satisfaction sebagai variabel mediasi. Artinya uji mediasi melalui sobel test diterima.

\section{Pengaruh Experiential Marketing terhadap Customer Satisfacion}

Menurut teori yang dijelaskan oleh Kotler dan Keller (2007, p.177), kepuasan konsumen adalah perasaan senang atau kecewa seseorang yang muncul setelah membandingkan kinerja (hasil) produk yang dipikirkan terhadap kinerja yang diharapkan. Hasil penelitian menunjukkan bahwa hipotesis pertama diterima. Penelitian ini ditunjang oleh R. Ozturk (2015) dengan subjek pelanggan kosmetik serta (Liu et al., 2016) diluar subjek restoran prasmanan menyatakan adanya hubungan positif antara experiential marketing terhadap customer satisfaction. Secara otomatis, hasil penelitian ini menolak penelitian dari (Alkilani et al., 2013) pada subjek pengguna telepon seluler dan (Araci et al., 2017) 
Grace Chintia Sutanto dan Tias Andarini Indarwati. Hubungan antara Experiential Marketing, Layanan Restoran Prasmanan, Customer Satisfaction, dan Customer Loyalty

dengan subjek industri makanan dan minuman yang menyatakan hubungan negatif antara experiential marketing terhadap customer satisfaction.

Pengalaman pengunjung Hanamasa terkait panca indera yaitu (sense) pada penelitian ini, mendominasi jawaban tertinggi para responden berkaitan dengan aroma dari proses memasak makanan Restoran Hanamasa dapat meningkatkan selera makan. Kepuasan konsumen sangat dirasakan ketika banyak responden setuju karena merasa harapan mereka terpenuhi saat makan di restoran Hanamasa. Kebanyakan responden mengaku mendapat informasi seputar Hanamasa melalui teman mereka. Jika dilihat dari data yang terkumpul, antara usia dengan sumber informasi, responden terbanyak yang menjadi konsumen Hanamasa ialah dengan rentang usia 19 tahun hingga 29 tahun yang merupakan usia muda produktif, memperoleh informasi tentang Restoran Hanamasa melalui teman mereka. Berarti, konsumen yang mendapat pengalaman yang tak terlupakan di Hanamasa karena kepuasan terhadap hidangannya ialah rata-rata berusia dewasa muda yang sering mendapatkan rekomendasi dari teman mereka. Hanamasa berhasil memberikan kepuasan ke konsumen sehingga konsumen yang puas dapat merekomendasikan kepada orang lain untuk dapat mengunjungi Hanamasa juga.

\section{Pengaruh Layanan Restoran Prasmanan Terhadap Customer Satisfacion}

Teori yang dijelaskan oleh (Ayse, 2007, p.53) menyatakan bahwa Harapan pelanggan merupakan faktor penting, kualitas layanan yang lebih dekat untuk kepuasan pelanggan akan memberikan harapan lebih dan sebaliknya. Sejalan dengan teori tersebut, hasil dari uji hipotesis pada penelitian ini menunjukkan bahwa hipotesis kedua diterima. Hasil penelitian ini juga mendukung hasil penelitian yang dilakukan oleh Ramanathan (2016) pada variabel penelitian layanan restoran prasmanan (buffet), menyatakan layanan restoran prasmanan berpengaruh signifikan terhadap customer satisfaction. Hasil dari penelitian ini menunjukkan bahwa layanan restoran prasmanan berpengaruh positif terhadap customer satisfaction secara langsung.

Responden dengan pendididkan akhir SMA mendominasi dalam penelitian ini. Karakteristik responden menyatakan responden dengan pendidikan terakhir SMA mendominasi frekuensi kunjungan, baik mengunjungi dua kali maupun mengundijungi lebih dari dua kali. Namun lebih jelasnya responden terbanyak adalah mereka yang mengunjungi sebanyak dua kali Berdasarkan jawaban responden mengenai pengukuran variabel layanan restoran prasmanan, pada indikator food and service banyak yang sangat setuju jika makanan yang disajikan Restoran Hanamasa masih segar. Kepuasan konsumen dirasakan ketika banyak dari responden setuju karena merasa puas terhadap layanan di Restoran Hanamasa. Meskipun kebanyakan pengunjung Hanamasa pada penelitian ini masih lulusan SMA, mereka mampu menilai kualitas layanan pada restoran prasmanan secara kritis karena memperhatikan kualitas hidangan dan kecakapan pelayan restoran sehingga menyimpulkan bahwa Hanamasa memiliki layanan khusus restoran prasmanan yang memuaskan.

\section{Pengaruh Customer Satisfaction terhadap Customer Loyalty}

Menurut teori yang dijelaskan oleh Vanessa (2007, p.72), yang menjelaskan bahwa loyalitas dipengaruhi oleh 5 faktor, dan salah satunya adalah kepuasan. Kepuasan adalah perbandingan antara harapan sebelum melakukan pembelian dengan kinerja yang dirasakan. Dalam hal ini pengunjung yang puas kepada Restoran Hanamasa sebagai restoran prasmanan Jepang bertaraf internasional. Sehingga pelanggan akan mengunjungi kembali restoran ala Jepang ini dan tidak mudah beralih ke aplikasi pesaing. Oleh karena itu banyak perusahaan yang berusaha untuk menjaga kepuasan konsumen pada penggunaan produk/ jasa mereka. Hasil dari penelitian ini menunjukkan bahwa customer satisfaction berpengaruh positif terhadap customer loyalty secara langsung. Hal tersebut menunjukkan bahwa hipotesis ketiga diterima. Hasil penelitian ini juga mendukung hasil penelitian yang dilakukan oleh El Adly (2018) dengan subjek pengunjung hotel dan Carranza dan Consuegra (2018) dengan subjek restoran fast food yang menyatakan customer satisfaction berpengaruh signifikan terhadap customer loyalty.

Kepuasan konsumen dirasakan ketika banyak dari responden setuju karena merasa puas terhadap layanan di Restoran Hanamasa. Loyalitas konsumen semakin dirasakan ketika banyak konsumen setuju untuk melakukan repeat purchase dengan ingin mengunjungi Restoran Hanamasa pada waktu 
mendatang. Mayoritas responden pada penelitian ini telah mengunjungi Hanamasa sebanyak dua kali. Responden yang dua kali berkunjung ke Hanamasa mendapat informasi dari teman mereka. Ini menunjukkan bahwa konsumen yang pernah datang, memasak makanannya sendiri dan menikmati beraneka makanan serta minuman telah mendapat kepuasan sehingga melakukan kunjungan kembali. Selain itu, konsumen yang puas secara sukarela merekomendasikan Hanamasa kepada teman mereka dan banyak juga yang mengajak teman mereka untuk mengunjungi Hanamasa. Hal ini menunjukkan sebagaian besar responden setuju dan mengetahui bahwa Restoran Hanamasa tidak hanya sebuah restoran yang memenuhi kebutuhan konsumen akan makanan ala Jepang, namun juga memberikan pengalaman positif tak terlupakan beserta layanan khusus restoran prasmanan sehingga menciptakan kepuasan tersendiri, membuat konsumen untuk berkunjung kembali, merekomendasikan kepada teman mereka secara sukarela dan akhirnya membuat konsumen menjadi loyal akan restoran tersebut.

\section{Pengaruh Experiential Marketing Terhadap Customer Loyalty}

Experiential marketing menurut Kertajaya (2010, p.23) adalah suatu konsep pemasaran yang bertujuan membentuk pelanggan yang loyal dengan cara menyentuh emosi pelanggan dengan menciptakan pengalaman-pengalaman positif dan memberikan suatu perasaan positif terhadap jasa dan produk mereka. Teori ini sesuai dengan hasil dari uji hipotesis yang dilakukan yang menunjukkan bahwa experiential marketing berpengaruh terhadap customer loyalty. Hasil dari penelitian ini menunjukkan bahwa experiential marketing memiliki hubungan yang berpengaruh positif terhadap customer loyalty secara langsung. Hal tersebut menunjukkan bahwa hipotesis keempat diterima. Penelitian ini ditunjang oleh penelitian dari Zena \& Hadisumarto (2012); Liu et al., (2016) serta Milman dan Tasci (2017) dengan subjek pengunjung taman hiburan yang menggunakan experiential marketing sebagai variabel independen dan menyatakan hubungan positif terhadap customer loyalty. Hasil yang berbeda ditunjukkan dari penelitian Fang dan Chao (2015) dengan subjek anggota fitness club yang menyatakan bahwa experiential marketing tidak berpengaruh signifikan terhadap customer loyalty. Semakin baik experiential marketing yang dilakukan oleh pihak Restoran Hanamasa, maka semakin konsumen akan semakin loyal terhadap restoran tersebut.

Responden yang mendominasi pada penelitian ini ialah perempuan usia sembilan belas hingga dua puluh sembilan tahun yang dikategorikan sebagai usia muda atau produktif. Konsumen Hanamasa yang telah berkunjung lebih dari dua kali yang paling dominan mahasiswa atau pelajar. Pengalaman yang berkaitan dengan penginderaan (sense) yang mendominasi jawaban tertinggi para responden. Seperti yang teah diketahui, makanan tidak hanya dirasakan oleh lidah, namun juga mata dan hidung. Aroma proses memasak yang dirasakan lewat indera penciuman semakin menggugah selera makan konsumen. Selain itu, loyalitas konsumen semakin dirasakan ketika banyak konsumen setuju untuk melakukan repeat purchase dengan ingin mengunjungi Restoran Hanamasa pada waktu mendatang. Inilah alasan dari experiential marketing yang dilakukan oleh Restoran Hanamasa dapat menyebabkan timbulnya customer loyalty.

\section{Pengaruh Layanan Restoran Prasmanan terhadap Customer Loyalty}

Vanessa (2007) menyatakan loyalitas dipengaruhi oleh 5 faktor, dan kualitas layanan tidak termasuk dalam lima faktor yang mempengaruhi loyalitas. Pada hasil penelitian ini, layanan restoran prasmanan tidak berpengaruh terhadap customer loyalty. Hal tersebut menunjukkan bahwa hipotesis kelima ditolak. Hasil ini ditunjang oleh penelitian Zena dan Hadisumarto (2012) pada kafe, menyatakan bahwa service quality berpengaruh tidak signifikan terhadap customer loyalty. Hasil penelitian ini tidak mendukung penelitian (Kuo et al., 2011) yang meneliti service quality pada industri restoran menyatakan adanya hubungan positif dan signifikan terhadap customer loyalty. Walaupun kualitas layanan dari Hanamasa baik, tidak secara otomatis membuat konsumen untuk tetap loyal. Saat ini banyak restoran ala Jepang dengan tipe all you can eat serupa menawarkan harga yang jauh lebih murah dari Hanamasa membuat konsumen selektif dalam memilih restoran Jepang dengan tipe all you can eat yang memiliki pilihan makanan berkualitas dan paling menguntungkan. Berdasarkan jawaban responden mengenai pengukuran variabel layanan restoran prasmanan, pada indikator price and value banyak konsumen yang kurang setuju terhadap penawaran harga, jika dibandingkan dengan manfaat yang dapat dinikmati konsumen pada restoran Hanamasa. Dengan harga tersebut, konsumen dapat 
menikmati semua hidangan yang ada di meja buffet (termasuk hidangan robatayaki, yakiniku, shabushabu dan dessert) sepuasnya dan langsung dimasak sendiri oleh konsumen di meja yang disediakan beserta bumbu masakan yang telah disiapkan. Sedangkan untuk varibel loyalitas pelanggan, banyak konsumen yang kurang setuju untuk tetap mengunjungi Restoran Hanamasa, meskipun banyak penawaran dari restoran Jepang lainnya. Dengan kata lain, banyak konsumen Hanamasa yang tetap ingin beralih untuk mencoba restoran Jepang lainnya. Hal ini menunjukkan sebagian besar responden masih banyak beranggapan bahwa harga yang diberikan Hanamasa masih kurang sesuai dengan manfaat yang diberikan. Ketika konsumen menyadari masih banyak restoran buffet konsep all you can eat serupa dengan Hanamasa yang menawarkan harga lebih murah ataupun harga lebih mahal namun memiliki manfaat yang sepadan, maka konsumen tersebut dengan mudahnya beralih ke restoran pesaing.

Pengeluaran terbanyak dari responden penelitian ini ialah kurang dari satu juta rupiah Hasil analisis antara pengeluaran per bulan dengan pekerjaan menyatakan, mahasiswa/pelajar dengan pengeluaran perbulan kurang dari satu juta rupiah memiliki jumlah terbanyak yaitu dua puluh empat responden. Mayoritas responden yang berjenis kelamin laki-laki dengan pengeluaran per bulannya sebesar kurang dari satu juta rupiah dengan kategori poor middle class dan untuk jenis kelamin perempuan dengan pengeluaran per bulan antara tiga juta rupiah hingga lima juta rupiah dengan kategori upper middle class. Konsumen dengan karakteristik tersebut merasa harga yang ditawarkan Hanamasa belum sesuai dengan manfaat yang diberikan, karena memiliki presentase yang besar jika digunakan untuk sekali waktu makan dibandingkan dengan pengeluaran per bulan. Untuk itulah Hanamasa perlu menambah manfaat yang diberikan kepada konsumen sehingga meskipun harga terbilang mahal untuk konsumen upper middle hingga poor middle class. Namun jika manfaat yang diperoleh sebanding, konsumen akan tetap setia mengunjungi Hanamasa.

\section{KESIMPULAN}

Berdasarkan data dari hasil penelitian dapat disimpulkan bahwa terdapat kepuasan dari pelanggan Hanamasa karena restoran ini mampu memberikan kesan positif yang mendalam serta memberikan pelayanan yang terbaik pada pelanggan sehingga sesuai harapan pelanggan. Dengan kata lain, experiential marketing dan layanan restoran prasmanan berhasil mempengaruhi customer satisfaction. terbukti pula bahwa customer satisfaction mampu menjadi mediasi pada customer loyalty. Experiential marketing melalui sense atau aroma dari proses memasak membuat konsumen ingin melakukan pembelian ulang sehingga terciptanya loyalitas, strategi ini perlu dipertahankan oleh Restoran Hanamasa. Namun, layanan restoran prasmanan belum mampu membuat pelanggan menjadi loyal sehingga pelanggan Hanamasa mudah beralih ke restoraan Jepang lainnya. Variabel layanan restoran prasmanan dan experiential marketing terhadap customer loyalty dengan customer satisfaction sebagai variabel mediasi yang digunakan dalam penelitian ini dapat digunakan sebagai pembanding bagi penelitian selanjutnya. Hasil penelitian ini diharapkan dapat menjadi masukan bagi pelaku usaha, khususnya bagi Restoran Hanamasa dalam menghadapi persaingan pada dunia bisnis kuliner dengan mempertimbangkan pengaruh experiential marketing, layanan restoran prasmanan, customer satisfaction, terhadap customer loyalty. Penelitian ini memiliki cakupan wilayah yang sangat terbatas yaitu di Kota Surabaya saja, sementara Restoran Hanamasa memiliki dua puluh cabang outlet yang tersebar di tiga pulau di Indonesia. Sebaiknya di penelitian mendatang cakupan wilayah dapat diperluas hingga pada konsumen Restoran Hanamasa di seluruh outlet Indonesia. Penelitian selanjutnya disarankan untuk menggunakan variabel independen selain experiential marketing dan layanan restoran prasmanan untuk mengetahui faktor-faktor lain yang mempengaruhi loyalitas seperti trust, choice reduction and habit, atau history with company.

\section{DAFTAR PUSTAKA}

Abd, Rachman Arief. (2005). Pengantar Ilmu Perhotelan dan Restoran Yogyakarta: Graha Ilmu 
Alkilani, K., Ling, K. C., \& Abzakh, A. A. (2017). The Impact of Experiential Marketing and Customer Satisfaction on Customer Commitment in the World of Social Networks. 9(1), 262-270. https://doi.org/10.5539/ass.v9n1p262

Andriani Kusumawati: (2011). Analisis pengaruh experiential marketing terhadap kepuasan dan loyalitas pelanggan: Kasus Hypermart Malang Town Square (MATOS) Vol. 3 No.1, ISSN 2085 0972

Araci, U. E., Bulut, Z. A., \& Kocak, N. (2017). the Relation Among Experiential marketing, Customer satisfaction, and Behavioral Intention: a Study on Food and Beverage Businesses. Economic and Social Development (Esd 2017), (September), 361-371.

Ayse, 2007. An evaluation on fast food preferences according to gender humanity and social science journal, Vol.2 Hal 43-50

Bps.go.id. 2019. Jumlah Rumah Makan/Restoran di Provinsi Jawa Timur Menurut Kabupaten/Kota, 2014-2018. (https://jatim.bps.go.id/statictable/2019/10/08/1578/jumlah-rumah-makan-restorandi-provinsi-jawa-timur-menurut-kabupaten-kota-2014-2018.html. Diakses 26 Oktober 2019).

Carranza, R., Díaz, E., \& Martín-consuegra, D. (2018). The in fl uence of quality on satisfaction and customer loyalty with an importance-performance map analysis Exploring the mediating role of trust. https://doi.org/10.1108/JHTT-09-2017-0104

Chao, R., \& Management, L. (2015). The Impact of Experimental Marketing on Customer Loyalty for Fitness Clubs : Using Brand Image and Satisfaction as the Mediating Variables. 10(2), 52-60.

Diab, Dr. Dahlia M. E., et al (2015). Investigation Of Dineserv Dimensions On Customer Satisfaction \& Loyalty: Evidences From The Restaurant Industry In Sudan.

El-adly, M. I. (2018). Journal of Retailing and Consumer Services Modelling the relationship between hotel perceived value, customer satisfaction, and customer loyalty. Journal of Retailing and Consumer Services, (xxxx), 0-1. https://doi.org/10.1016/j.jretconser.2018.07.007

Engel, Blackwell, Miniard. (2012). Perilaku Konsumen. Tangerang: Binarupa Aksara

Griffin, Jill. 2005. Customer Loyalty: Menumbuhkan \& Mempertahankan Kesetiaan Pelanggan. Jakarta : Erlangga.

Hanamasaresto.com. 2020. Sejarah Hanamasa. (https://www.hanamasaresto.com/about. Diakses pada 24 Januari 2020).

Indarwati, T. A., Tiarawati, M., \& Kunci, K. (n.d.). Strategi Pemasaran Melalui Experience dan Emotional Marketing Terhadap Kepuasan dan Loyalitas Pelanggan Di J. Co Donuts \& Caffee Surabaya, 102-117.

Ivkov, M., Blesic, I., Stefanovic, V., \& Raljic, J. P. (2014). Managing Customer satisfaction In The Restaurant Industry: A Word From Managers. Economic Themes, 52(3), 369-378.

Kertajaya, Hermawan. 2010. Connect! Surfing new Wave Marketing. Jakarta: Gramedia Pustaka Utama.

Kim, K., \& Choi, K. (2019). Bridging the Perception Gap between Management and Customers on DINESERV Attributes: The Korean All-You-Can-Eat Buffet. 
Grace Chintia Sutanto dan Tias Andarini Indarwati. Hubungan antara Experiential Marketing, Layanan Restoran Prasmanan, Customer Satisfaction, dan Customer Loyalty

Kuo, N. T., Chang, K. C., Cheng, Y. S., \& Lai, C. H. (2011). The Impact of Service Quality , Customer satisfaction and Loyalty in the Restaurant Industry : Moderating Effect of Perceived Value, 551555 .

Kompasiana.com. 2019. Pergikuliner. (https://www.kompasiana.com/pergikuliner. Diakses tanggal 4 Februari 2020).

Kotler, Philip. (2007). Marketing Management. Edition Twelve. PT. Indeks. Jakarta.

Kotler, Philip. 2009. Manajemen Pemasaran. Jakarta: Erlangga

Liu, Y. and Jang, S., "Perceptions of Chinese restaurants in the U.S.: What affects customer satisfaction and behavioral intentions," International Journal of Hospitality Management, vol. 28, pp. 338$348,2009$.

Lovelock, Cristopher H. dan Wright, Lauren K. 2005. Manajemen Pemasaran Jasa. PT. Indeks Kelompok Gramedia. Jakarta.

Stamenkovic, M., \& Milanovic, M. (2018). The relationship between service quality in students restaurant and customer loyalty QUALITY IN STUDENTS ' RESTAURANT AND, (June 2015).

Milman, A., \& Tasci, A. D. A. (2017). Journal of Destination Marketing \& Management Exploring the experiential and sociodemographic drivers of satisfaction and loyalty in the theme park context. Journal of Destination Marketing \& Management, June, 1-11. https://doi.org/10.1016/j.jdmm.2017.06.005

Noegroho, Ody Adam, Suharyono, \& Koemadji, S. 2013. Pengaruh Experiential marketing dan Brand Trust terhadap Kepuasan Pelanggan dan Loyalitas Pelanggan KFC cabang kawi Malang. Malang: Universitas Brawijaya.

Oyewole, P. (2012). Journal of Hospitality Marketing \& Multiattribute Dimensions of Service Quality in the All-You-Can-Eat Buffet Restaurant Industry Multiattribute Dimensions of Service Quality in the All-You-Can-Eat Buffet Restaurant Industry, (February 2015), 37-41. https://doi.org/10.1080/19368623.2011.638418

Öztürk, R., \& Marketing, A. E. (2015). Exploring the Relationships between Experiential Marketing, Customer Satisfaction and Customer Loyalty : An Empirical Examination in Konya, 9(8), 24852488 .

Patel, Vivek. (2019). How Restaurants Can Use Experiential marketing to Boost Their Business. Modernrestaurantmanagement.com.(https://modernrestaurantmanagement.com/howrestaurantscan-use-experiential-marketing-to-boost-theirbusiness/, Diakses pada10 Februari 2020).

Raab, C., \& Mayer, K. (2007). Menu engineering and activity-based costing - can they work together in a restaurant ?, 19(1), 43-52. https://doi.org/10.1108/09596110710724152

Rahmani, A. (2018, Maret 12). Faktor Kepuasan Pelanggan untuk Mengembangkan Bisnis. Retrieved Juni 19, 2018, from www.jurnal.id: https://www.jurnal.id/id/blog/2018/ mengenal-faktorkepuasanpelanggan-untuk-sukses-berbisnis.

Ramanathan, Ramakrishnan (2016). Moderating roles of customer characteristics on the link between service factors and satisfaction in a buffet restaurant. Vol. 23 Iss 2 page 1-22. http://dx.doi.org/10.1108/BIJ-01-2015-0012 
Restofocus.com. 2019. Mengenal Lebih Dekat Restoran All You Can Eat. (https://www.restofocus.com/2016/03/mengenal-lebihdekat-restoran-all-you.html. Diakses pada 6 Maret 2020).

Schmitt, Bernd. (1999). Experiential marketing. 37-41.

Suzana, M., Raspor, S., \& Segaric, K. (2010). Does Restaurant Performance Meet Customers ' Expectations ? An Assessment of Restaurant Service Quality Using a Modified Dineserv Approach Does Restaurant Performance Meet Customers ' Expectations ? An Assessment Of Restaurant Service Quality Using A Suza, (December 2015).

Tjiptono, Fandy. 2001. Manajemen Pemasaran dan Analisa Perilaku Konsumen, Yogyakarta: BPFE.

Tjiptono, Fandy. 2008 .Strategi Pemasaran, Edisi III, Yogyakarta : CV. Andi Offset

Traveloka.com. 2019. Restaurants Indonesia City Surabaya. (https://www.traveloka.com/enid/restaurants/indonesia/city/surabaya-103570. Diakses pada 20 Februari 2020)

Tripadvisorsuport.com. 2019. Pedoman untuk Ulasan Wisatawan. (https://www.tripadvisorsupport.com/hc/id/articles/200614797-Pedoman-untuk-ulasanwisatawan. Diakses tanggal 17 Februari 2020).

Vanessa, Gaffar. (2007). Customer Relationship Management and Marketing Public Relations. Bandung: Alfabeta.

Warisan dan Harianto (2018). Faktor Yang Mempengaruhi Keputusan Konsumen Dalam Memilih Restoran “All You Can Eat” Di Surabaya. Universitas Kristen Petra.

Wei, W. C., \& Hung F. H. (2010). The empirical study of the relation among experiential marketing, customer satisfaction, and customer loyalty the moderating and mediating effect of product involvement. International Journal of Lisrel, 3(2), 15-30.

Wijayanto. (2019). Potensi Industri F\&B Mampu Tumbuh 20 Persen Tahun Ini. Radarsurabaya.jawapos.com.(https://radarsurabaya.jawapos.com/read/2019/02/22/120908/pote nsi-industri-fb-mampu-tumbuh-20-persen-tahun-ini, diakses pada 19 Oktober 2019).

Wu, M.-Y., \& Tseng, L.-H. (2014). Customer satisfaction and Loyalty in an Online Shop: An Experiential marketing Perspective. International Journal of Business and Management, 10(1), 104-115. https://doi.org/10.5539/ijbm.v10n1p104

Y. R. Chen, Y. C. Lee, "Effects of Experiential marketing on Blog Loyalty", Marketing Review, 6(4), 591-616, 2009.

Zena, P. A., \& Hadisumarto, A. D. (2012). The Study of Relationship among Experiential marketing , Service Quality, Customer satisfaction, and Customer loyalty, (1), 37-46.

Zulaikha, Mimi. (2019). Tingkatkan Kontribusi Kuliner pada PDB Nasional, Bekraf Gelar FSI 2019

Bekraf.go.id.

(https://www.bekraf.go.id/subsektor/page/kuliner, diakses 25 Oktober 2019). 